
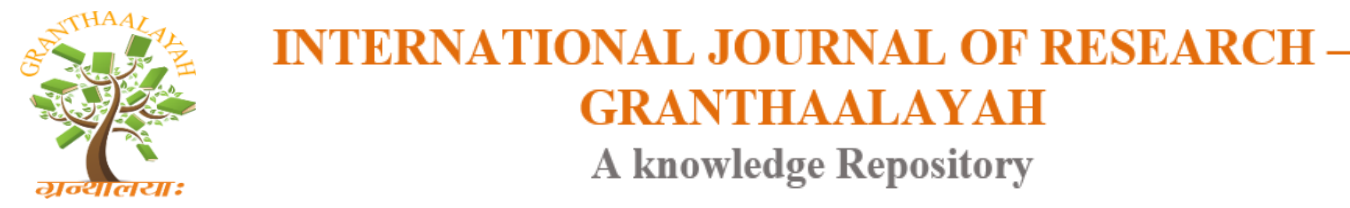

Social

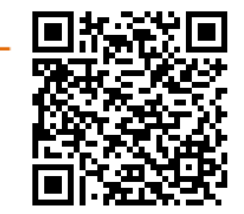

\title{
HEALTH PRACTICES OF HIGH SCHOOL STUDENT IN KANYAKUMARI DISTRICT
}

\author{
Sudha. $\mathrm{N}^{* 1}$, Mrs. S.Padmakala ${ }^{2}$ \\ ${ }^{* 1}$ MEd Scholar, M.E.T College of Education, Chenbagaramanputhur, India \\ ${ }^{2}$ Assistant Professor in General Education, M.E.T College of Education, Chenbagaramanputhur, \\ Kanyakumari district, India
}

DOI: https://doi.org/10.29121/granthaalayah.v5.i3(SE).2017.1933

\begin{abstract}
The present study was conducted to know the health practices of high school students in Kanyakumari district. The investigator collected data from 420 high school students in Kanyakumari district. The data obtained were analyzed by using statistical techniques such as mean, standard deviation, t-test, ANOVA and correlation. The obtained results showed that there exists a moderate level of health practices among high school students in Kanyakumari district.

Keywords: Health; High Secondary School; Students \& Disease.

Cite This Article: Sudha. N, and Mrs. S.Padmakala. (2017). "HEALTH PRACTICES OF HIGH SCHOOL STUDENT IN KANYAKUMARI DISTRICT." International Journal of Research - Granthaalayah, 5(3)SE, 33-39. https://doi.org/10.29121/granthaalayah.v5.i3(SE).2017.1933.
\end{abstract}

\section{Introduction}

Health is wealth. It is related deeply to life-style, i.e., the individual's way of living, personal hygiene, habits and behaviour. The health practices are considered as "Teach Health, Not Disease". It says that teachers should teach health practices, how to live healthfully how to protect one's body against infection rather than teaching about diseases and medicines.

Health plays a vital role in human life. According to Article 25 of the Universal Deceleration of human rights, everyone has the right to have a standard of living with adequate health of himself, including food, clothing, housing, medical care, and necessary services. The school being the main agency of education has a vital role in providing health practices to the students. It should instruct and guide students in such things such as the structure and functioning of their bodies, the causes and method of preventing common diseases, the factors that contributes to sound health and the role of the community in maintaining good health. 
Neat, clean, attractive and well-maintained institutional buildings, class rooms, equipment's, play fields, sympathetic and affectionate teachers contribute greatly to inculcate healthy living, healthy habits, healthy work conditions and healthy surroundings. Because all these aspects of the environment of the institution play a key role in achieving success.

Normally, health practices include balanced and nutritive diet, physical exercise, recreation, rest and sleep, habits of cleanliness to body organs, dress and dwelling place, knowledge and structure of the various organs of the body, functioning of various system of the body, knowledge of various common diseases their causes, symptoms, precautionary measures and cure, sanitation of home, school, neighborhood, community slums, cities, factory areas, markets, villages, health centers and their functioning as centers of health practices. Schools are the best place to promote health by providing the latest scientific information. Teachers can install positive health attitudes and habits by providing opportunities for preservation of health. In schools, the teachers and at home, the parents can make provisions for the young boys and girls to practice hygienic living.

Government policy, documents proposals and research reports reveal the current health status and health practices of our nation. Many more studies are to be undertaken to resolve health issues in the country. Even today, the young generation does not have adequate health practices in the daily life. We know that the young generation is the pillar of our future India. So health practice of young generation at all walks of life is a must.

The students of today will be the citizen's and leaders of tomorrow so the investigator has undertaken this study to find out the health practices of high school students.

\section{Significance of the Study}

Health is a valuable asset for all individuals. Hygienic conditions, protection from infections, prevention and treatment of diseases, provision for adequate nutrition and regulated life style and systematic exercise are considered as factors associated with sound health. Knowledge of health education assumes greater significance in India, because where most of the people in India are ignorant about the basic principles of health and hygiene. Because of this ignorance, they are unable to prevent the diseases, which are otherwise preventable. Therefore is an urgent need to remove this ignorance from our masses. People are to be made aware of the fundamental and basic principles of health habits which alone can help in preventing and eradicating many of the silent and killer diseases prevalent in our country.

Health education programmers are basically preventive and primitive in nature. As prevention is better than cure. Health programmers are very important in transmitting the knowledge, making the people aware of various dreaded diseases and occurrences of which could be easily avoided. In this way, health education plays an important role in eliminating many problems that adversely affect young people, adult and society in general.

Hence, health education has a very significant role to play as it comprises health knowledge, health habits and health attitudes. It can improve the individual, family and community life for a bright and prosperous future. Health education thus helps an individual to distinguish between 
good and bad health habits and encourage one to make good habits as enduring and lasting healthful behaviours. Health education thus is essential to assure that proper health habits are established early in life, so that habits and behaviours adopted in childhood remain unchanged throughout life. The good health habits instilled in children during their formative years reflect in their life, making them healthy, useful and effective citizen of the country. In this way health education contributes greatly to our national growth.

Health is freedom from diseases and sickness. To keep our health well, we should follow the laws of health and hygiene. Food, exercise, rest sleep, regular habits, neatness and cleanliness, punctuality and peace of mind are the primary conditions for good health. Hence, we should do regular activities neatly and clearly. Further we should be sincere in our duties and daily activities.

A healthy person not only contributes towards the progress of his family, community or the nation but also helps in raising the economic standard of his country. The health of the individual and the society in which he lives are interdependent. Since, habits play an important role in effective schooling development of all faculties of the learner and his happiness and success in life is very important for one's whole same development.

Now- a- days all the young students especially youth are addicted to the modern life style. They have no time to restore or maintain proper health. Hence schools are the best place to promote health by providing the latest and scientific information. Teachers can develop positive health attitudes and habits by providing opportunities for the preservation of health. In schools, the teachers and at home, the parents can make provisions for the young boys and girls to practice hygienic living. Today, health and hygiene being an urgent issue this topic on "Health Practices of High School Students in Kanyakumari district", has been selected.

\section{Review of Literature}

Ray Zaman Laskar, (2015) conducted a study on hand washing practices in two communities of two states of India. The objectives of the study were to find out the hand washing practices followed in two urban slums as well as to assess and compare the status of different components of hand washings at the pre and post-intervention phases. This community based cross sectional intervention study was carried out at two urban slums with more or less similar socio cultural linguistic background. The study was carried out by using an interview technique as well as observation. Interpersonal communication for behavioural change was chosen as a method of intervention. The majority (90\%) practiced hand washing after defecations in both the study areas. Significant improvement was observed in the hand washing after intervention in both the areas. The practices of hand washing were observed in some situations and needed attention. Use of soap and clean material for drying hands after hand washings was poor initially but showed improvement after intervention.

Geeta (1998) studied "Physical health status and locus of control on higher secondary school students". The study focussed on the physical health status of student's in general of the higher secondary school students. The main objectives were: 1) to find out whether there is any significant difference between the boys and girls in physical health status. 2) To find out whether there is any significant difference between the students of different communities in physical health status. 3) To find out the difference between the students of different religious groups in 
physical health status. 4) To find out whether there is any significant difference between the students of different income groups in physical health status. Results were: There was significant difference between male and female students in emotional maturity, self-confidence and physical health. Hindu and Muslim students differed significantly in their physical health. Christian and Muslim students did not differ significantly in the physical health. Rural and urban students did not differ significantly in the physical health.

Kohli and Batra (2010) conducted a study on "Lifestyle and Health Habits among young males and females". The objectives: to explore the different lifestyle and health habits of young male and female subjects. Lifestyle and habit questionnaire by Nevid, Rathus and Rebenstein was administrated on 200 subjects (100 males and 100 females) of 20-26 years age group. Data were statistically analyzed by using t-test. The study showed women to have better health practices. No significant difference was found in four health domains i.e. physical health, exercise, and physical fitness, spiritual health and psychological health. In general subjects were not having an excellent health.

\section{Statement of the Problem}

\section{A STUDY ON HEALTH PRACTICES OF HIGH SCHOOL STUDENTS IN KANNYAKUMARI DISTRICT.}

\section{Objectives Framed}

- To find out the level of health practices of high school students under study.

- To study the significant difference between the mean scores of Health Practices based on the background variables namely gender, medium of instruction, school locality, student locality and types of family.

- To study the significant difference between the mean scores of Health Practices based on the background variables namely religion, community, type of management and family income.

\section{Hypotheses Formulated}

- The health practices of high school students are at moderate level.

- There is no significant difference in the mean scores of Health Practices based on the background variables namely gender, medium of instruction, locality of school, student locality.

- There is no significant difference in the mean scores of Health Practices based on the background variables religion, community, type of management and family income.

\section{Sample of the Study}

The total sample of the present study consisted of 420 high school students studying in various schools located in kanyakumari district. The students were selected by using stratified random sampling technique. 
Tools

For the present study the investigator made use of;

- Health practices Inventory for high school students developed and validated by the investigator.

\section{Statistical Techniques Used}

In order to analyses and interpret data the following statistical measures were used

- Descriptive analysis - Mean, Standard Deviation

- Differential analysis - ' $t$ ' test and ' $F$ ' test

\section{Analysis and Interpretation of Data}

The study has been analysed systematically and given in different table.

\section{Results and Discussion}

The results of percentage the analysis are given table-1

\section{Analysis and Interpretation}

\section{Hypotheses 1:}

\section{The health practices of high school students are at moderate level}

Table 1: Data and results of percentage analysis, Level of health practices of high school students

\begin{tabular}{|c|l|l|l|}
\hline \multicolumn{1}{|c|}{ Variable } & Groups compared & \multicolumn{1}{c|}{ N } & \multicolumn{1}{c|}{ Percentage } \\
\hline \multirow{4}{*}{ Health practices } & Low & 117 & 27.9 \\
\cline { 2 - 5 } & Medium & 198 & 47.1 \\
\cline { 2 - 5 } & High & 105 & 25.0 \\
\cline { 2 - 5 } & Total & 420 & 100.0 \\
\hline
\end{tabular}

From table-1, it is evident from the study that only 25 percent of high school students under study have high level of health practices and 27.9 percent have low level of health practices, majority of the students 47.5 percent have a medium level with regard to health practices. Therefore the hypotheses- 1 which states the health practices of high school students are at moderate level is accepted.

\section{Hypothesis 2:}

There is no significant difference in the mean scores of Health Practices based on the background variables namely gender, medium of instruction, locality of school, student locality 
Table 2: Comparison of mean scores of Health Practices based on background variables namely gender, medium of instruction, type of family, student locality, locality of school

\begin{tabular}{|c|c|c|c|c|c|c|}
\hline Variables & Category & $\mathbf{N}$ & Mean & SD & t-test & $\begin{array}{c}\text { Level of } \\
\text { Significance }\end{array}$ \\
\hline \multirow{2}{*}{ Gender } & Male & 202 & 18.05 & 4.305 & \multirow{2}{*}{1.201} & \multirow{2}{*}{ Not significant } \\
\hline & Female & 218 & 18.56 & 4.307 & & \\
\hline \multirow{2}{*}{$\begin{array}{l}\text { Medium of } \\
\text { instruction }\end{array}$} & Tamil & 260 & 18.43 & 4.350 & \multirow{2}{*}{0.715} & \multirow{2}{*}{ Not significant } \\
\hline & English & 160 & 18.13 & 4.247 & & \\
\hline \multirow{2}{*}{$\begin{array}{l}\text { Type of } \\
\text { family }\end{array}$} & Joint & 130 & 19.24 & 4.524 & \multirow{2}{*}{2.963} & \multirow{2}{*}{$\begin{array}{l}\text { Significant at } \\
\text { 0.01 level }\end{array}$} \\
\hline & Nuclear & 290 & 17.90 & 4.150 & & \\
\hline \multirow{2}{*}{$\begin{array}{l}\text { Student } \\
\text { locality }\end{array}$} & Rural & 195 & 18.51 & 4.216 & \multirow{2}{*}{0.868} & \multirow{2}{*}{ Not significant } \\
\hline & Urban & 225 & 18.15 & 4.389 & & \\
\hline \multirow{2}{*}{$\begin{array}{l}\text { Locality of } \\
\text { school }\end{array}$} & Rural & 180 & 18.34 & 4.175 & \multirow{2}{*}{0.114} & \multirow{2}{*}{ Not significant } \\
\hline & Urban & 240 & 18.30 & 4.414 & & \\
\hline
\end{tabular}

Table-2 reveals that the obtained t- value of the health practices of high school students in terms of their gender, medium of instruction, student locality, locality of school are less than table values 1.96 at 0.05 level of significance. Hence it is inferred that the high school students do not differ significantly with respect to the gender, medium of instruction, student locality and locality of school. But significant difference was noted with respect to type of family. Therefore, the null hypothesis formed has been accepted in four cases and rejected in the case of type of family.

\section{Hypothesis 3:}

There is no significant difference in the mean scores of Health Practices based on the background variables religion, community, type of management and family income.

Table 3: Comparison of Health Practices of high school students belonging to various religion, management, community and family income

\begin{tabular}{|c|c|c|c|c|c|c|}
\hline Variables & Sources & $\begin{array}{c}\text { Sum of } \\
\text { Squares }\end{array}$ & df & $\begin{array}{l}\text { Mean and } \\
\text { Square }\end{array}$ & F value & $\begin{array}{c}\text { Level of } \\
\text { signification }\end{array}$ \\
\hline \multirow[t]{2}{*}{ Religion } & Between group & 2.262 & 2 & 1.131 & \multirow[t]{2}{*}{0.061} & \multirow{2}{*}{$\begin{array}{l}\text { Not } \\
\text { Significant }\end{array}$} \\
\hline & Within group & 7774.621 & 417 & 18.644 & & \\
\hline \multirow[t]{2}{*}{ Management } & Between group & 99.780 & 2 & 49.890 & \multirow[t]{2}{*}{2.710} & \multirow{2}{*}{$\begin{array}{l}\text { Not } \\
\text { Significant }\end{array}$} \\
\hline & Within group & 7677.104 & 417 & 18.410 & & \\
\hline \multirow[t]{2}{*}{ Community } & Between group & 59.233 & 3 & 19.744 & \multirow[t]{2}{*}{1.064} & \multirow{2}{*}{$\begin{array}{l}\text { Not } \\
\text { Significant }\end{array}$} \\
\hline & Within group & 7717.651 & 416 & 18.552 & & \\
\hline \multirow{2}{*}{$\begin{array}{l}\text { Family } \\
\text { Income }\end{array}$} & Between group & 91.293 & 4 & 22.823 & \multirow[t]{2}{*}{1.232} & \multirow{2}{*}{$\begin{array}{l}\text { Not } \\
\text { Significant }\end{array}$} \\
\hline & Within group & 7685.590 & 415 & 18.519 & & \\
\hline
\end{tabular}


Table-3 reveals that the obtained ' $F$ ' value of the high school students in terms of their religion, management, community and family income are less than table value 3.02 at 0.05 level of significance. Hence it can be inferred that the high school students did not differ in their health practices with respect to the religion, community, management and family income. Therefore the null hypothesis is accepted.

\section{Findings of the Study}

- The health practices of high school students are at moderate level.

- There is no significant difference in their health practices of high school students with respect to Gender, Medium of Instruction, Locality of school, Student locality. But a significance of difference was noted in the health practices of high school students with respect to the type of family.

- There is no significant difference in the health practices of high school students with respect to Religion, Community, Management and Family income. But a significance of difference was noted in the health practices of high school students with respect to the type of family.

\section{Conclusion}

The above study reveals that overall health practices of high school students is of moderate level. It also reveals that t-test, ANOVA, have revealed that there exists no significant difference in health practices of high school students with respect to the back ground variable like gender, medium of Instruction, locality of school, students locality, religion, community, management, and family income, except the type of family.

\section{References}

[1] Biswas, D. \& Kumar, S. (2013). Health Awareness among the secondary school students in Purulia District. Indian Stream Research Journal. 2(12), 1-4.

[2] Golden, S. A. R. (2017). Recent Research In Social Science \& Humanities.

[3] Kohil, S \& Batra, P. (2010). Life style and Health Habits amongst young males and females. Behavioural scientist. 11(1), 3-16.

[4] Parthasarathy, K. \& Durga, (2006). A study on Health and Nutritional Practices of SC Mothers. Journal of Adult Education and Extension, 2(2), 29-37.

[5] World Health Organization, (2010). Physical and health education. Priyakamal publication, maduari-10, 7.1-7.2. 